\title{
Regulation of intracellular calcium levels by polyunsaturated fatty acids, arachidonic acid and docosahexaenoic acid, in astrocytes: possible involvement of phospholipase $\mathrm{A}_{2}$
}

\author{
Marina SERGEEVA ${ }^{\mathrm{a}, \mathrm{b}}$, Mikhail STROKIN ${ }^{\mathrm{a}}$, Georg REISER ${ }^{\mathrm{a} *}$ \\ a Otto-von-Guericke-Universität Magdeburg, Medizinische Fakultät, Institut für Neurobiochemie, \\ Leipziger Strasse 44, 39120 Magdeburg, Germany \\ b Belozersky Institute of Physico-Chemical Biology, Moscow State University, Moscow, Russia
}

(Received 28 February 2005; accepted 9 May 2005)

\begin{abstract}
Pathological conditions in the brain, such as ischemia, trauma and seizure are accompanied by increased levels of free $n-6$ and $n-3$ polyunsaturated fatty acids (PUFA), mainly arachidonic acid (AA, 20:4n-6) and docosahexaenoic acid (DHA, 22:6n-3). A neuroprotective role has been suggested for PUFA. For investigation of the potential molecular mechanisms involved in neuroprotection by PUFA, we studied the regulation of the concentration of intracellular $\mathrm{Ca}^{2+}$ $\left(\left[\mathrm{Ca}^{2+}\right]_{\mathrm{i}}\right)$ in rat brain astrocytes. We evaluated the presence of extracellular PUFA and the release of intracellular PUFA. Interestingly, only the constitutive brain PUFA AA and DHA, but not eicosapentaenoic acid (EPA) had prominent effects on intracellular $\mathrm{Ca}^{2+}$. AA and DHA suppressed $\left[\mathrm{Ca}^{2+}\right]_{\mathrm{i}}$ oscillation, inhibited store-operated $\mathrm{Ca}^{2+}$ entry, and reduced the amplitudes of $\mathrm{Ca}^{2+}$ responses evoked by agonists of $\mathrm{G}$ protein-coupled receptors. Moreover, prolonged exposure of astrocytes to AA and DHA brought the cells to a new steady state of a moderately elevated $\left[\mathrm{Ca}^{2+}\right]_{\mathrm{i}}$ level, where the cells became virtually insensitive to external stimuli. This new steady state can be considered as a mechanism of self-protection. It isolates disturbed parts of the brain, because AA and DHA reduce pathological overstimulation in the tissue surrounding the damaged area. In inflammation-related events, frequently AA and DHA exhibit opposite effects. However, in astrocytes AA and DHA exerted comparable effects on $\left[\mathrm{Ca}^{2+}\right]_{\mathrm{i}}$. Extracellularly added AA and DHA, but not EPA, were also able to induce the release of $\left[{ }^{3} \mathrm{H}\right] \mathrm{AA}$ from prelabeled astrocytes. Therefore, we also suggest the involvement of phospholipase $\mathrm{A}_{2}$ activation and lysophospholipid generation in the regulation of intracellular $\mathrm{Ca}^{2+}$ in astrocytes.
\end{abstract}

arachidonic acid / docosahexaenoic acid / eicosapentaenoic acid / prostglandins / cycloxygenase / CNS / essential fatty acid / neuroprotection

\begin{abstract}
Abbreviations: AA: arachidonic acid; $\mathrm{AACOCF}_{3}$ : arachidyltrifluoromethylketone; cAMP: cyclic adenosine monophosphate; ATP: adenosine 5'-triphosphate; $\left[\mathrm{Ca}^{2+}\right]_{\mathrm{i}}:$ concentration of free intracellular $\mathrm{Ca}^{2+}$; $\mathrm{CaM}$ : calmodulin; CIF: calcium influx factor; CPA: cyclopiazonic acid; DHA: docosahexaenoic acid; EPA: eicosapentaenoic acid; $\mathrm{IP}_{3}$ : inositol 1,4,5-trisphosphate; MAPK: mitogen-activated protein kinase; $\mathrm{PLA}_{2}$ : phospholipase $\mathrm{A}_{2}$; iPLA $_{2}$ : calcium independent $\mathrm{PLA}_{2}, \mathrm{CPLA}_{2}$, cytosolic PLA 2 ; PUFA: polyunsaturated fatty acid; PKA: protein kinase A; SERCA: sarcoplasmic/ endoplasmic-reticulum $\mathrm{Ca}^{2+}$-ATPase; SOC: store-operated $\mathrm{Ca}^{2+}$ channel.
\end{abstract}

\footnotetext{
* Corresponding author: Georg.Reiser@Medizin.Uni-Magdeburg.de
} 


\section{INTRODUCTION}

\subsection{Polyunsaturated fatty acids, astrocytes, and brain functions}

Changes in structural and functional integrity of the brain appear to correlate with alterations in membrane concentrations of polyunsaturated fatty acids (PUFA) [1]. The brain contains not only the n-6 PUFA arachidonic acid (AA), but is also highly enriched in the n-3 PUFA docosahexaenoic acid (DHA) [2]. In contrast, in peripheral tissues, phospholipids do not accumulate prominent amounts of n-3 PUFA and, therefore, cannot serve as a reservoir.

The membrane composition concerning the proportion of n-3 and n-6 PUFA in phospholipids has been shown to be crucial for normal functioning of the central nervous system (CNS) (reviewed in [3-5]). Pathophysiological conditions, such as ischemia, trauma and seizure, are associated with increased levels of free DHA and AA in the brain tissue reaching up to micromolar concentrations [6-11]. A potential neuroprotective function of polyunsaturated fatty acids for cerebral pathologies has been suggested [12, 13]. Moreover, important roles of PUFA in psychosis, schizophrenia, and creativity have been discussed [14, 15]. Hence, molecular mechanisms of action of PUFA have significant practical value.

PUFA are mainly released via activation of phospholipases $\mathrm{A}_{2}$, which hydrolyze the sn-2 bond of cellular phospholipids generating free acids and lysophospholipids. More than 19 different isoforms of PLA 2 have been described in the mammalian system, but recent studies have focused on four major groups, namely, the group IV cytosolic $\mathrm{PLA}_{2}\left(\mathrm{CPLA}_{2}\right)$, the groups II and V secretory $\mathrm{PLA}_{2}$, and the group VI Ca ${ }^{2+}$-independent $\mathrm{PLA}_{2}\left(\mathrm{iPLA}_{2}\right)$ [16]. $\mathrm{CPLA}_{2}$ is activated by elevation of the concentration of free intracellular $\mathrm{Ca}^{2+}\left(\left[\mathrm{Ca}^{2+}\right]_{\mathrm{i}}\right)$ and/or by phosphorylation by mitogen-activated protein kinase (MAPK). cPLA 2 preferentially hydrolyzes phospholipids containing
AA and plays a key role in the biosynthesis of eicosanoids [17]. Recent evidence has established the physiological and pathological roles of the isoform $\mathrm{cPLA}_{2} \alpha$. Using cPLA $_{2} \alpha$ knockout mice, it has been shown that this enzyme is implicated in postischemic brain injury (reviewed in [17]). Relatively little is known concerning the regulation of iPLA $_{2}$. Two isoforms of iPLA $_{2}$ derived from different genes have been described $[18,19]$. All major PLA isoenzymes are present in the CNS (reviewed in $[20,21])$. However, their detailed role in PUFA release is still a matter of ongoing investigations.

Astrocytes, an important type of glial cells, are very active in the metabolism of PUFA [22-25]. Astrocytes, but not neurons, are capable of elongation and desaturation of essential fatty acids (linoleic and alpha-linolenic acids). For the supply of AA and DHA, neurons depend upon astrocytes [26]. Astrocytes are capable of converting AA into prostaglandins, leukotrienes and epoxygenase metabolites [22, 27] and are also sensitive to feedback regulation by prostaglandins [28]. Notably, activation of many of the metabotropic receptors in astrocytes is associated with AA release and production of prostaglandins [29-35]. We have shown in astrocytes, which were activated by different stimuli, that AA is mainly released by the $\mathrm{Ca}^{2+}$-dependent $\mathrm{PLA}_{2}$ $\left(\mathrm{cPLA}_{2}\right)$. However, the release of DHA which is induced simultaneously with AA is mediated by $\mathrm{Ca}^{2+}$-independent $\mathrm{PLA}_{2}$ $\left(\mathrm{iPLA}_{2}\right)$ sensitive to the $\mathrm{iPLA}_{2}$ specific inhibitor bromoenol lactone [36]. Additionally, we have found that the release of AA and DHA is differently regulated through $\mathrm{Ca}^{2+}$ - and cAMP-dependent signal transduction pathways [36].

Astrocytes are able to communicate with each other and with neurons via oscillations in $\left[\mathrm{Ca}^{2+}\right]_{i}[37,38]$. Functional coupling of cells in different tissues and organs by way of $\mathrm{Ca}^{2+}$ is an important mechanism for controlling and synchronizing physiological responses (for review, see [39]). During the 
last few years, a great amount of evidence has been accumulated to demonstrate an active role of astrocytes in the physiology of the nervous system as dynamic regulatory elements in neurotransmission. $\mathrm{Ca}^{2+}$ in astrocytes is a key element for the mutual regulation of neurons and glia [40]. In addition, a plethora of receptors expressed by astrocytes is associated with $G$ proteins that upon activation stimulate the formation of inositol 1,4,5-trisphosphate $\left(\mathrm{IP}_{3}\right)$, which leads to an increase of $\left[\mathrm{Ca}^{2+}\right]_{\mathrm{i}}$ through $\mathrm{Ca}^{2+}$ release from $\mathrm{IP}_{3}$-sensitive internal $\mathrm{Ca}^{2+}$ stores [28, 41-45]). Our recent studies demonstrated that astrocytes acutely release both DHA and AA after activation by the neurotransmitters glutamate and bradykinin and proinflammatory substances, such as ATP and thrombin [36]. All these substances are agonists of $\mathrm{G}$ protein-coupled receptors involved in the regulation of $\mathrm{Ca}^{2+}$ signaling in astrocytes. Hence, the presence of extracellular PUFA and the conditions of intracellular PUFA release should be taken into consideration in studies of cellular $\mathrm{Ca}^{2+}$ signaling.

\subsection{Mechanisms of regulation of $\mathrm{Ca}^{2+}$}

One of the most important cellular signaling pathways is a change in $\left[\mathrm{Ca}^{2+}\right]_{\mathrm{i}}$. Changes in $\left[\mathrm{Ca}^{2+}\right]_{i}$ play a pivotal role in the regulation of a wide range of cellular processes [46]. Stimulation of many plasma membrane receptors by different stimuli is associated with an increase in $\left[\mathrm{Ca}^{2+}\right]_{\mathrm{i}}$. The increase of $\left[\mathrm{Ca}^{2+}\right]_{\mathrm{i}}$ is attributed to the release of $\mathrm{Ca}^{2+}$ from intracellular stores, first of all the endoplasmic reticulum [47], and an influx of $\mathrm{Ca}^{2+}$ across the plasma membrane [48]. There is evidence for the presence of two distinct mechanisms for the activation of $\mathrm{Ca}^{2+}$ influx by agonists in non-excitable cells, (i) a capacitative mechanism that is dependent on the depletion of intracellular $\mathrm{Ca}^{2+}$ stores $[47,49]$ and (ii) a non-capacitative mechanism whereby $\mathrm{Ca}^{2+}$ entry is not affected by the store content [50]. Capacitative $\mathrm{Ca}^{2+}$ entry, which can be readily demonstrated in almost all non-excitable cells, is responsible for replenishing depleted intracellular stores [51, 52]. Probable candidates of channels responsible for this $\mathrm{Ca}^{2+}$ entry are members of the TRPC (canonical transient receptor potential) family [52]. Models for the activation of capacitative $\mathrm{Ca}^{2+}$ entry involve a direct interaction between plasma membrane channels and $\mathrm{Ca}^{2+}$ release channels on the intracellular stores or participation of a diffusible factor, the calcium influx factor (CIF) (see [51, 52] for review). A direct interaction between TRPC and two families of intracellular $\mathrm{Ca}^{2+}$ release channel, $\mathrm{IP}_{3}$ receptors and ryanodine receptors, has been demonstrated (see [52] for review). It is becoming increasingly clear that stimulation of cells with agonists that invoke the production of $\mathrm{Ca}^{2+}$-releasing messengers promotes multiple $\mathrm{Ca}^{2+}$ entry pathways [50, 53, 54].

In many non-excitable cells, activation of plasma membrane receptors with an agonist at low concentrations leads to $\left[\mathrm{Ca}^{2+}\right]_{\mathrm{i}}$ oscillations. Although in some instances oscillations result from the cycling of $\mathrm{Ca}^{2+}$ between intracellular stores and the cytoplasm [55], in most cases the transport of $\mathrm{Ca}^{2+}$ across the plasma membrane is crucial $[56-58]$. Maintenance of $\left[\mathrm{Ca}^{2+}\right]_{\mathrm{i}}$ oscillations has been explained by some models, which implicate either capacitative $\mathrm{Ca}^{2+}$ entry $[59,60]$, or non-capacitative $\mathrm{Ca}^{2+}$ entry [61-64]. In the scenario involving capacitative $\mathrm{Ca}^{2+}$ entry, this pathway is necessary for the refilling of the stores. Thus, the oscillation frequency is controlled by the refilling time [65]. Authors supporting the noncapacitative entry theory acknowledge the importance of store refilling during the response to stimuli which produce massive $\mathrm{Ca}^{2+}$ release from the stores, but they stress the lack of direct evidence which could confirm the notion that capacitative entry plays a role for "weak" stimuli that generate oscillations [66]. The arachidonate-regulated $\mathrm{Ca}^{2+}$ current, I(ARC), was suggested as a candidate for non-capacitative $\mathrm{Ca}^{2+}$ entry [67]. This hypothesis is very attractive due to the fact that many different stimuli induce the release of AA in various cells. 
Thus, the n-6 PUFA AA, besides serving as a precursor of prostaglandins and leukotrienes, may also have an important role as a signal molecule for non-capacitative $\mathrm{Ca}^{2+}$ entry associated with oscillations $[63,64$, $66,68]$. Other PUFA like DHA and eicosapentaenoic acid (EPA) seem to attenuate $\mathrm{Ca}^{2+}$ signalling in different cells. Thus, $\mathrm{Ca}^{2+}$ influx is suppressed by DHA in cardiac myocytes [69] and smooth muscle cells [70].

Numerous data show the beneficial effects of n-3 PUFA, first of all DHA and EPA, in many pathological conditions, in comparison to the n-6 PUFA AA $[1,71-73]$. DHA might possibly attenuate the production of prostaglandins from AA by direct inhibition of cyclooxygenases. However, the action of PUFA is not restricted to the regulation of prostaglandin production. Molecular mechanisms of a direct involvement of PUFA in cell functions remain elusive. Studies of the action of n-3 and n-6 PUFA on intracellular $\mathrm{Ca}^{2+}$ could clarify this issue.

\section{MATERIALS AND METHODS}

All experimental details for establishing astrocyte cultures and measuring cytosolic $\mathrm{Ca}^{2+}$ by Fura- 2 fluorescence are those described before [32, 74]. Briefly, primary astrocyte cell cultures were prepared from newborn rat brains and plated on round coverslips (22 $\mathrm{mm}$ diameter) placed in culture dishes (50 $\mathrm{mm}$ diameter) and incubated at $37{ }^{\circ} \mathrm{C}$ with $10 \% \mathrm{CO}_{2}$, humidified to saturation. For the experiments, the cells were used between days 7 and 12 in culture. The concentration of free intracellular $\mathrm{Ca}^{2+}$ $\left(\left[\mathrm{Ca}^{2+}\right]_{\mathrm{i}}\right)$ was measured using the $\mathrm{Ca}^{2+}$ sensitive fluorescent dye Fura-2/AM. For dye loading, the cells grown on a coverslip were placed in $1 \mathrm{~mL}$ HEPES-buffered saline (HBS) (buffer composition in mM: 145 $\mathrm{NaCl}, 5.4 \mathrm{KCl}, 1 \mathrm{MgCl}_{2}, 1.8 \mathrm{CaCl}_{2}, 25$ glucose, 20 HEPES, pH 7.4 adjusted with tris(hydroxymethyl)-aminomethane)) for $30 \mathrm{~min}$ at $37^{\circ} \mathrm{C}$, supplemented with $2 \mu \mathrm{M}$ Fura-2/AM. Loaded cells were transferred into a perfusion chamber with a bath vol- ume of about $0.2 \mathrm{~mL}$ and mounted on an inverted microscope. During the experiments, the cells were continuously superfused with medium heated to $37^{\circ} \mathrm{C}$. For the experiments, the cells on the coverslip were chosen randomly and usually they were all the cells in the area of observation. The cells were excited alternately at $340 \mathrm{~nm}$ and $380 \mathrm{~nm}$ for $50-70 \mathrm{~ms}$ at each wavelength with a rate of $0.33 \mathrm{~Hz}$ and the resultant emission collected above $510 \mathrm{~nm}$. Images were stored on a computer and subsequently the changes in fluorescence ratio $\left(\mathrm{F}_{340} / \mathrm{F}_{380}\right)$ were determined from selected regions of interest covering a single cell. Fluorescence ratios from the same day measurement were compared. In part of the experiments, autofluorescence was determined at the end of each experiment and fluorescence ratios were calculated after substraction of autofluorescence and calibrated as free $\left[\mathrm{Ca}^{2+}\right]_{\mathrm{i}}$ according to a standard protocol [75].

\section{RESULTS AND DISCUSSION}

\subsection{Involvement of polyunsaturated fatty acids (PUFA) in $\mathrm{Ca}^{2+}$ regulation in astrocytes}

Here we attempt to give an overview of the role of PUFA in $\mathrm{Ca}^{2+}$ signaling in astrocytes. We have studied the influence of AA, DHA, and EPA on thrombin- [32] and ATP-induced $\mathrm{Ca}^{2+}$ responses [74]. We could show that the effects of AA are not mediated by its oxidative metabolites generated via 5-lipoxygenase, cyclooxygenase and cytochrome P450 monooxygenase pathways $[32,74]$. Thus the effects of fatty acids themselves on $\mathrm{Ca}^{2+}$ regulation in rat astrocytes will be evaluated further. First, we observed that simultaneous addition of exogenous AA or DHA $(10 \mu \mathrm{M})$ decreased the amplitude of initial $\mathrm{Ca}^{2+}$ responses to ATP and thrombin by $25 \%$, both in the presence and absence of extracellular calcium (for details see the experiment testing AA in Fig. 1A). In the presence of $10 \mu \mathrm{M}$ AA 

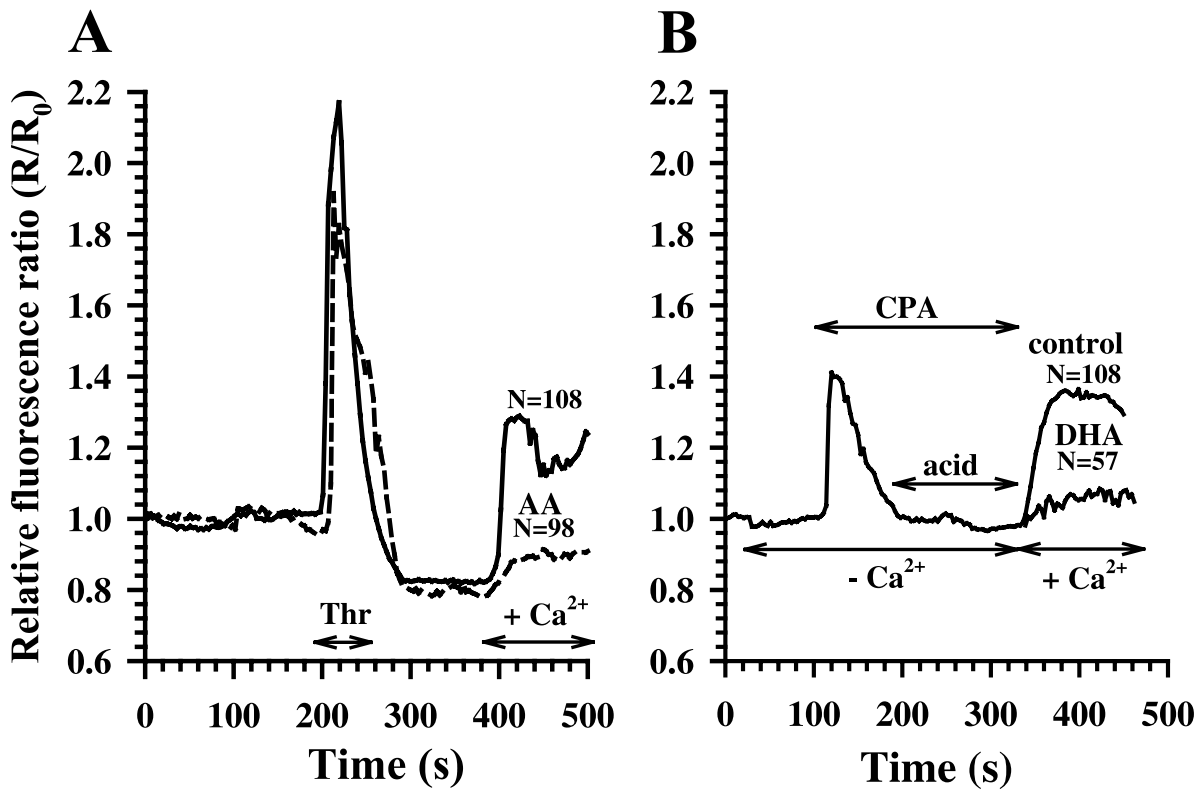

Figure 1. PUFA inhibit $\mathrm{Ca}^{2+}$ responses to thrombin (A) and reduce store-operated $\mathrm{Ca}^{2+}$ entry in astrocytes. Changes in $\left[\mathrm{Ca}^{2+}\right]_{i}$ are presented as relative values $\left(\mathrm{R} / \mathrm{R}_{0}\right)$, where $\mathrm{R}$ is the fluorescence ratio $\left(\mathrm{F}_{340 \mathrm{~nm}} / \mathrm{F}_{380 \mathrm{~nm}}\right)$ in the cells loaded with fura-2/AM, referred to $\mathrm{R}_{0}$, which is the $\mathrm{R}$ value at the beginning of the experiment. (A) The influence of AA on thrombin-induced $\mathrm{Ca}^{2+}$ release from stores and the following $\mathrm{Ca}^{2+}$ influx after readdition of extracellular $\mathrm{Ca}^{2+}$. From the beginning of the experiment cells were superfused with $\mathrm{Ca}^{2+}$-free buffer. At the time period indicated by the arrow (Thr), cells were perfused for $1 \mathrm{~min}$ either with $0.1 \mathrm{U} \cdot \mathrm{mL}^{-1}$ thrombin alone (solid line trace; number $(\mathrm{N})$ of cells tested $=108$ ) or for $1 \mathrm{~min}$ with $0.1 \mathrm{U} \cdot \mathrm{mL}^{-1}$ thrombin together with $10 \mu \mathrm{M}$ of AA (broken line; number $(\mathrm{N})$ of cells tested $=98$ cells). After another $3 \mathrm{~min}, \mathrm{Ca}^{2+}$ was replenished in the extracellular medium. (B) Influence of PUFA on $\mathrm{Ca}^{2+}$ entry after store depletion by SERCA inhibitor cyclopiazonic acid (CPA). Store depletion was induced by CPA $(10 \mu \mathrm{M})$ in $\mathrm{Ca}^{2+}$-free medium, followed by addition for 2 min of PUFA (acid $10 \mu \mathrm{M}$ ) as indicated by the arrows. Storeoperated $\mathrm{Ca}^{2+}$ entry was measured as the amplitude of $\left[\mathrm{Ca}^{2+}\right]_{\mathrm{i}}$ increase after the addition of $\mathrm{Ca}^{2+}$ into the extracellular buffer (time period marked by $+\mathrm{Ca}^{2+}$ ). The example with the acid DHA is shown in B. Typical traces are given.

or DHA we observed a dramatic decrease of store-operated $\mathrm{Ca}^{2+}$ influx. The decrease was $65 \%$ and $45 \%$, respectively. The $\mathrm{Ca}^{2+}$ trace example for AA is given in Figure 1A. EPA $(10 \mu \mathrm{M})$ was again ineffective. Thus, AA and DHA can attenuate agonist-induced $\mathrm{Ca}^{2+}$ signals by a dual negative regulation. Firstly, there is a slight reduction of the amount of agonist-induced $\mathrm{Ca}^{2+}$ release from intracellular stores and secondly, there is a strong inhibition of the following $\mathrm{Ca}^{2+}$ influx.

We also analyzed the direct influence of AA, DHA and EPA on the capacitative
$\mathrm{Ca}^{2+}$ influx stimulated by depletion of intracellular $\mathrm{Ca}^{2+}$ stores by using inhibitors of SERCA (sarcoplasmic/endoplasmicreticulum $\mathrm{Ca}^{2+}$-ATPase), such as cyclopiazonic acid (CPA) or thapsigargin, in $\mathrm{Ca}^{2+}$ free medium. As shown in the example in Figure 1B, after store depletion by addition of CPA, DHA was added for 2 min and then $\mathrm{Ca}^{2+}$ was replenished in the extracellular medium. With application of $10 \mu \mathrm{M} \mathrm{DHA}$, we observed an $80 \%$ decrease of the $\mathrm{Ca}^{2+}$ influx. AA $(10 \mu \mathrm{M})$ was similarly effective. EPA $(10 \mu \mathrm{M})$ had a weak suppressive effect 


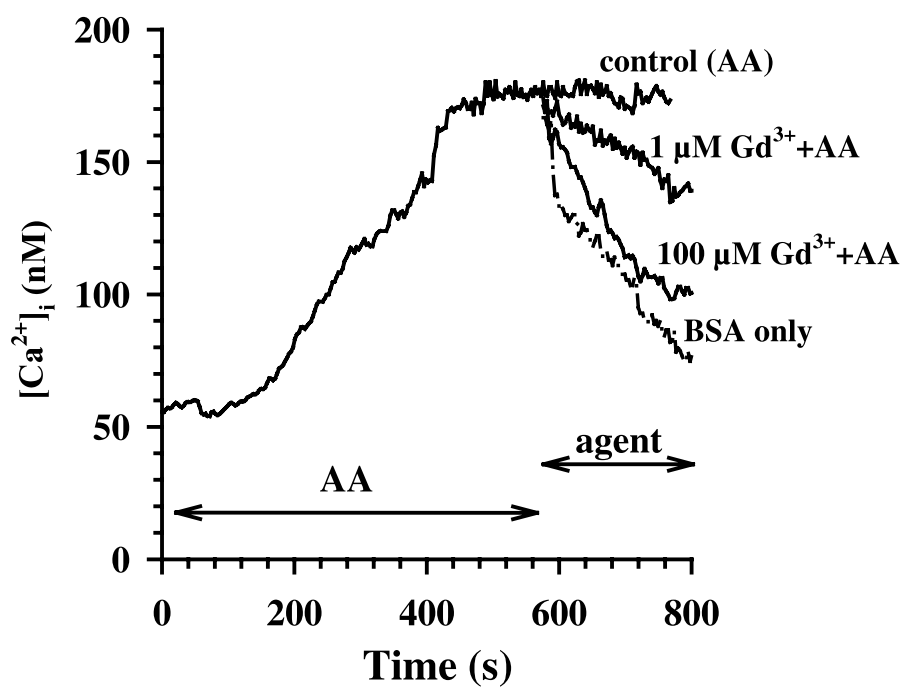

Figure 2. Induction of $\mathrm{Ca}^{2+}$ influx by arachidonic acid (AA) in astrocytes. Astrocytes were stimulated with $10 \mu \mathrm{M}$ AA during the time periods indicated by the arrow marked AA. After reaching the plateau, $\mathrm{Gd}^{3+}(1$ or $100 \mu \mathrm{M}$, number of the cells tested were 20 and 80 , respectively) together with $10 \mu \mathrm{M}$ AA, or BSA $(0.1 \%)$ alone (53 cells tested) were added, during the time period indicated by an arrow marked agent. $\left[\mathrm{Ca}^{2+}\right]_{\mathrm{i}}$ was measured in the cells loaded with fura-2/AM as described in the Materials and methods. Typical traces are presented.

of less than $30 \%$ on $\mathrm{Ca}^{2+}$ entry after CPAinduced depletion of intracellular stores. For thapsigargin the inhibitory effect for both DHA and AA was 55\%. EPA $(10 \mu \mathrm{M})$ had no influence. SERCA-induced $\mathrm{Ca}^{2+}$ influx in astrocytes was reduced to a similar degree by $1 \mu \mathrm{M} \mathrm{Gd}^{3+}$ [74]. The lanthanide $\mathrm{Gd}^{3+}$ can discriminate between capacitative and non-capacitative $\mathrm{Ca}^{2+}$ entry pathways. Capacitative $\mathrm{Ca}^{2+}$ entry is sensitive to blockade by $1 \mu \mathrm{M} \mathrm{Gd}^{3+}$, while non-capacitative $\mathrm{Ca}^{2+}$ entry is inhibited only at higher $\mathrm{Gd}^{3+}$ concentrations [76, 77]. Thus the channels, which are inhibited by PUFA may be attributed to store-operated $\mathrm{Ca}^{2+}$ channels (SOC).

Incubation of astrocytes with $10 \mu \mathrm{M}$ AA or DHA for 30 min decreased the $\mathrm{Ca}^{2+}$ store content after that exposure by 55 and $40 \%$, respectively. $\mathrm{Ca}^{2+}$ store content was determined by the response to CPA. EPA $(10 \mu \mathrm{M})$ was not effective (see [32] for details). The data described in the previous paragraph suggest that the decrease in store content by
PUFA is most likely a result of the inhibition of SOC. Depletion of the $\mathrm{Ca}^{2+}$ stores was also observed in Ehrlich ascites tumor cells [78]. However the authors attribute this effect to $\mathrm{Ca}^{2+}$ release by AA from the stores.

In the absence of $\mathrm{Ca}^{2+}$ in the extracellular medium, no influence of PUFA on the $\left[\mathrm{Ca}^{2+}\right]_{\mathrm{i}}$ level of astrocytes was observed. This result differentiates astrocytes from several other cell systems, where AA-induced release of $\mathrm{Ca}^{2+}$ from stores has been shown [78-80]. In the presence of $\mathrm{Ca}^{2+}$ in the extracellular medium, $10 \mu \mathrm{M}$ AA induced after prolonged incubation an increase in the $\left[\mathrm{Ca}^{2+}\right]_{\mathrm{i}}$ level by approximately $150 \mathrm{nM}$ (Fig. 2). Also, the addition of DHA led in a comparable concentration-dependent manner to a delayed moderate increase in $\left[\mathrm{Ca}^{2+}\right]_{\mathrm{i}}$ (data not shown). The response displayed two distinct phases. As shown in Figure 2, after a delay of 1-2 min, a slow increase was seen reaching a new steady state after 4-5 $\mathrm{min}$ of application. This increase 

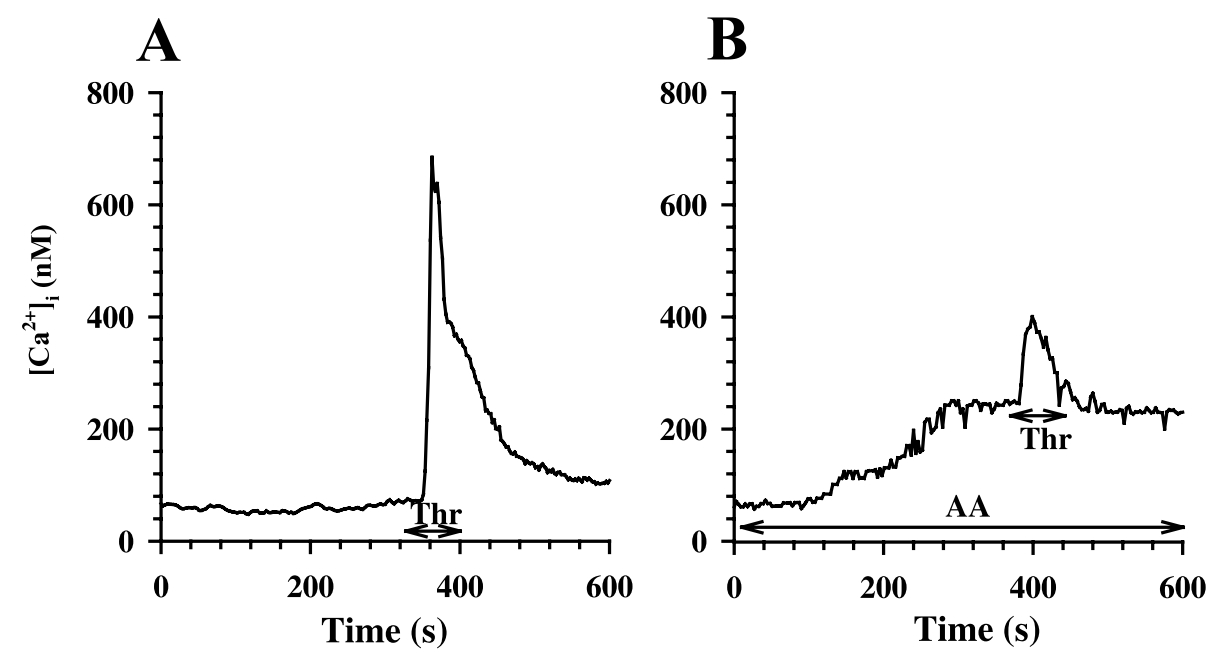

Figure 3. Prolonged incubation of rat brain astrocytes with AA dampens thrombin-induced $\left[\mathrm{Ca}^{2+}\right]_{\mathrm{i}}$ response. Control astrocytes ( 94 cells tested) (A) and astrocytes treated with $10 \mu \mathrm{M}$ AA ( 23 cells tested) $(\mathbf{B})$ were stimulated with $0.1 \mathrm{U} \cdot \mathrm{mL}^{-1}$ thrombin $(\mathrm{Thr})$ during the time periods indicated by the arrows. $\left[\mathrm{Ca}^{2+}\right]_{\mathrm{i}}$ was measured in the cells loaded with fura-2/AM as described in the Materials and methods. Typical traces are presented.

was reversed by the addition of $\mathrm{Gd}^{3+}[74]$ or by washing the cells with bovine serum albumin $(0.1 \%)$, which binds and scavenges PUFA. It is important to note that $100 \mu \mathrm{M}$ $\mathrm{Gd}^{3+}$ decreased $\left[\mathrm{Ca}^{2+}\right]_{\mathrm{i}}$ with a kinetics that was comparable with that observed during washing with albumin. This result indicates that AA and DHA induce $\left[\mathrm{Ca}^{2+}\right]_{\mathrm{i}}$ increase through channels which display the same sensitivity to $\mathrm{Gd}^{3+}$ as non-capacitative $\mathrm{Ca}^{2+}$ entry channels. However, when AA was added simultaneously with $1 \mu \mathrm{M} \mathrm{Gd}^{3+}$, there was absolutely no increase of $\left[\mathrm{Ca}^{2+}\right]_{\mathrm{i}}$ in the astrocytes [74]. This also indicates that capacitative $\mathrm{Ca}^{2+}$ entry is a prerequisite for AA- and DHA- induced increase in $\left[\mathrm{Ca}^{2+}\right]_{i}$.

\subsection{PUFA-induced steady elevation in $\left[\mathrm{Ca}^{2+}\right]_{i}$ blocks $\mathrm{Ca}^{2+}$ responses in astrocytes}

As outlined above, AA and DHA have two opposite, but time-separated effects on intracellular $\mathrm{Ca}^{2+}$ in astrocytes. Firstly, AA and DHA acutely block capacitative $\mathrm{Ca}^{2+}$ influx. Secondly, after prolonged exposure to AA and DHA a $\mathrm{Ca}^{2+}$ influx is activated that leads to the establishment of a new basal level of $\mathrm{Ca}^{2+}$ in astrocytes. This behavior can be described by a mathematical model of two steady states (so-called bistability), which has been developed for simulation of cellular signaling networks. This model suggests that in cellular systems, where two pathways are activated by the same stimulus, frequently both pathways are necessary to be active to reach a new steady state for a cellular parameter (in our case $\left.\left[\mathrm{Ca}^{2+}\right]_{i}\right)[81,82]$.

The concentration of free intracellular calcium in resting cells is the equilibrium between several influx and efflux processes. After application of $10 \mu \mathrm{M}$ of DHA or AA and establishment of a new steady state for $\mathrm{Ca}^{2+}$, the ability of astrocytes to respond to external stimuli was drastically reduced. The amplitude of the initial $\mathrm{Ca}^{2+}$ responses to thrombin and ATP fell from 600-800 nM (Fig. 3A) to only approximately $100 \mathrm{nM}$ (Fig. 3B), as exemplified here for the response to thrombin in the presence of $10 \mu \mathrm{MAA}$. This may have great 
physiological importance for astrocyte functions during pathological conditions, when increased extracellular levels of PUFA occur. The cells reached a new steady state level of $\left[\mathrm{Ca}^{2+}\right]_{\mathrm{i}}$, which was probably not high enough to trigger $\mathrm{Ca}^{2+}$-dependent pathways. Therefore, the ability to respond to further activation by different stimuli was lost. The mechanism, which led to the reduction of responses to thrombin and ATP, is most likely the reduction of the $\mathrm{Ca}^{2+}$ content in cellular stores of astrocytes. A similar mechanism has been suggested for the suppression of $\mathrm{Ca}^{2+}$ responses caused by bradykinin and thrombin after treatment of Ehrlich ascites tumor cells with AA [78]. This suggests a widespread importance of such mechanisms for regulation of $\mathrm{Ca}^{2+}$ for several cell types.

In order to find further evidence for the physiological significance of elevated levels of PUFA, we investigated the influence of AA and DHA on ATP-induced $\left[\mathrm{Ca}^{2+}\right]_{\mathrm{i}}$ oscillations in astrocytes [83] and compared it with the effects of EPA (Fig. 4). Oscillations were induced by ATP and then $10 \mu \mathrm{M}$ of PUFA was added to the perfusion medium. AA blocked the oscillations (Fig. 4A), as reported previously [32]. DHA $(10 \mu \mathrm{M})$ also blocked the oscillations in all experiments and induced a $\left[\mathrm{Ca}^{2+}\right]_{\mathrm{i}}$ increase to a moderately elevated steady state (Fig. 4B). EPA, however, did not influence the oscillations or even increase their frequency (Fig. 4C). Thus, extracellular DHA and AA block ATP-induced $\left[\mathrm{Ca}^{2+}\right]_{i}$ oscillations, which are considered to be an important part of astrocyte functions and allow astrocytes to communicate between each other and neurons [84].

The ATP-induced $\left[\mathrm{Ca}^{2+}\right]_{\mathrm{i}}$ oscillations in astrocytes were controlled by channels sensitive to $\mathrm{Gd}^{3+}$ at $100 \mu \mathrm{M}$, but not to $1 \mu \mathrm{M}$ of $\mathrm{Gd}^{3+}$ (Fig. 4D). This finding allowed implying the non-capacitative type of $\mathrm{Ca}^{2+}$ channels in the oscillations. Studies from the Shuttleworth [85] and Taylor groups [86] have demonstrated the importance of endogenous AA in the activation of non-capaci- tative channels and the involvement of these channels in agonist-induced $\left[\mathrm{Ca}^{2+}\right]_{\mathrm{i}}$ oscillations in some cell types. Previously, we have shown that the release of endogenous AA in astrocytes depends upon the activity of cytosolic PLA 2 [36]. Therefore, we used inhibitors of $\mathrm{PLA}_{2}$ to investigate the possible role of endogenous AA. $\mathrm{AACOCF}_{3}$, a general inhibitor of $\mathrm{PLA}_{2}$, was employed to investigate the possible role of endogenous AA in ATP-induced oscillations. The addition of $10 \mu \mathrm{M}$ of $\mathrm{AACOCF}_{3}$ to the superfusion system $10 \mathrm{~min}$ before ATP or during ATP-induced $\left[\mathrm{Ca}^{2+}\right]_{\mathrm{i}}$-oscillations did not block the oscillations (data not shown). Therefore, the involvement of endogenous AA release in the regulation of $\left[\mathrm{Ca}^{2+}\right]_{i}$ oscillations in astrocytes is still unclear. Experiments using different types of inhibitors of $\mathrm{PLA}_{2}$ are required to resolve this issue.

\section{CONCLUSIONS AND OUTLOOK: PROTECTIVE EFFECT OF AA AND DHA, BUT NOT EPA, ON NEURAL TISSUE}

The constitutively abundant brain PUFA, AA and DHA, have various effects on different pathways of $\left[\mathrm{Ca}^{2+}\right]_{\mathrm{i}}$ regulation in astrocytes. These PUFA inhibit store-operated $\mathrm{Ca}^{2+}$ entry, reduce the amplitudes of responses to agonists of $\mathrm{G}$ protein-coupled receptors, and suppress $\left[\mathrm{Ca}^{2+}\right]$ oscillation. Moreover, prolonged exposure of astrocytes to AA and DHA drives the cells into a new steady state with moderately elevated $\left[\mathrm{Ca}^{2+}\right]_{\mathrm{i}}$, where cells become virtually insensitive to external stimuli. We propose that this new steady state can be considered as an important part of the neuroprotective mechanisms of PUFA, because AA and DHA released by disturbed parts of the brain protect surrounding cells from pathological overstimulation.

The scheme describing the mechanism of involvement of PUFA, AA and DHA, in $\mathrm{Ca}^{2+}$-triggered physiological and pathological processes in astrocytes is presented in 
A

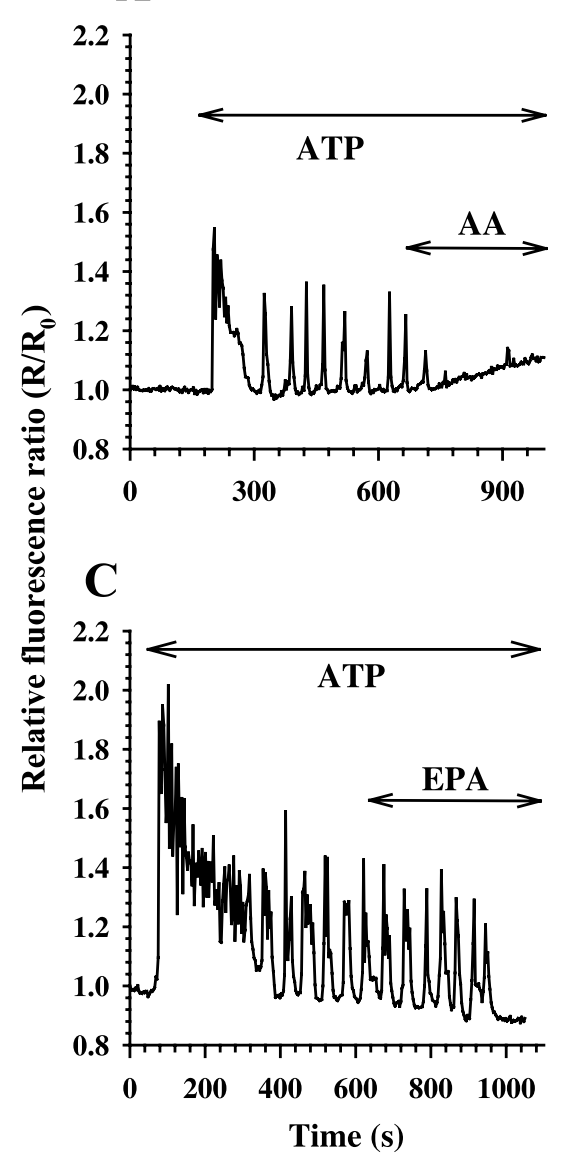

B

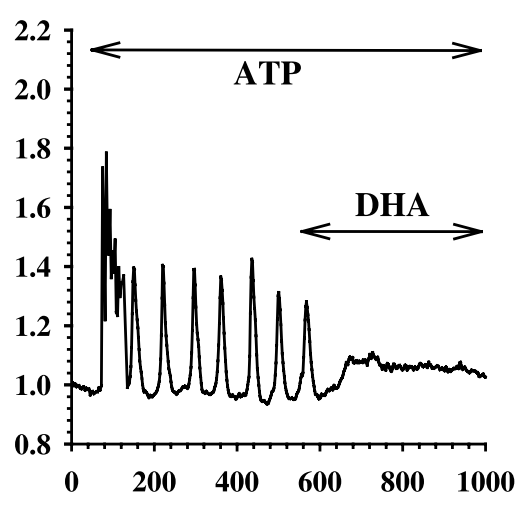

D

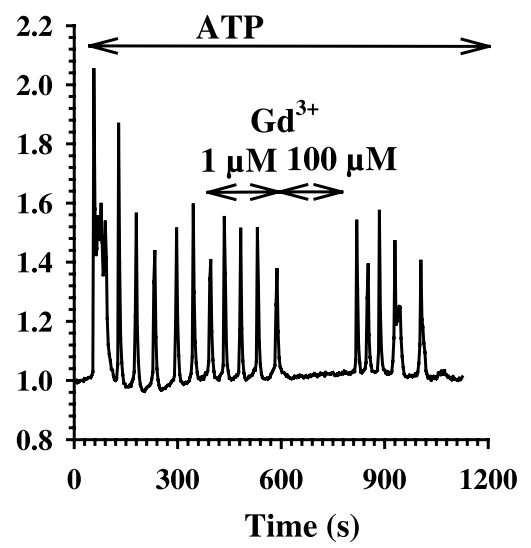

Figure 4. AA and DHA, but not EPA suppress the ATP-induced $\left[\mathrm{Ca}^{2+}\right]_{\mathrm{i}}$ oscillations in astrocytes. Fura-2-loaded cells were stimulated as indicated by arrows with ATP $(10 \mu \mathrm{M})$ to induce $\left[\mathrm{Ca}^{2+}\right]_{i}$ oscillations, before $10 \mu \mathrm{M}$ of AA (94 cells tested) (A), DHA (72 cells tested) (B) or EPA (84 cells tested) $(\mathbf{C})$ were added, as indicated. (D) Astrocytes were stimulated with ATP $(10 \mu \mathrm{M})$ to induce $\left[\mathrm{Ca}^{2+}\right]_{\mathrm{i}}$ oscillations and then $\mathrm{Gd}^{3+}$ was added, as indicated by the arrows (33 cells tested). ATP-induced $\left[\mathrm{Ca}^{2+}\right]_{i}$ oscillations in astrocytes were suppressed by high $\mathrm{Gd}^{3+}$ concentration specific for noncapacitative $\mathrm{Ca}^{2+}$ entry channels, but not by low concentrations of $\mathrm{Gd}^{3+}$ specific for capacitative $\mathrm{Ca}^{2+}$ channels. Typical traces are presented. $\mathrm{R} / \mathrm{R}_{0}$ was measured in the cells loaded with fura-2/AM, as described in Figure 1.

Figure 5. Stimulation of astrocytes by agonists induces $\left[\mathrm{Ca}^{2+}\right]_{\mathrm{i}}$ changes from the resting level of $80 \mathrm{nM}$ to $500-1000 \mathrm{nM}$ during spikes or oscillations. This activates different $\mathrm{Ca}^{2+}$ sensors, which augment a wide range of $\mathrm{Ca}^{2+}$-sensitive processes. The release of small amounts of endogenous AA could participate in "on-mechanisms", which acutely decrease normal calcium responses (right part in Fig. 5). Most importantly, the excess of PUFA released outside the cells could stimulate the elevation of $\left[\mathrm{Ca}^{2+}\right]_{\mathrm{i}}$ to a new steady state of $\left[\mathrm{Ca}^{2+}\right]_{\mathrm{i}}$, which has an intermediate level of 150-200 nM. At this elevated level, the cells become insensitive to agonist stimulation; $\left[\mathrm{Ca}^{2+}\right]_{\mathrm{i}}$ spikes and 


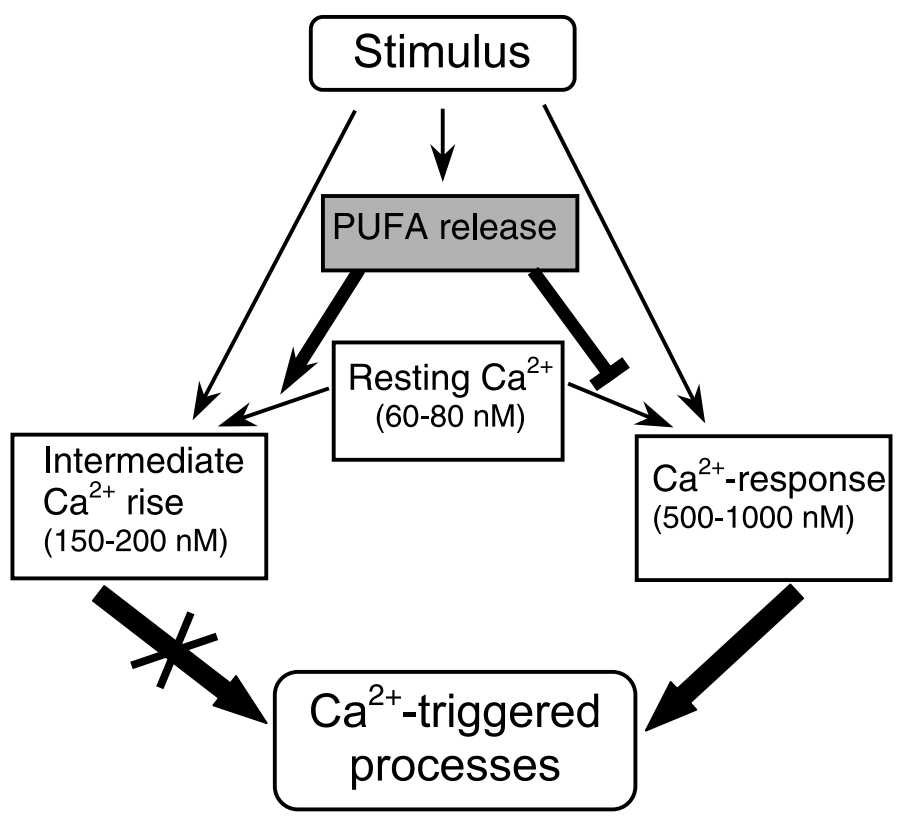

Figure 5. Pathways of suppression of cellular $\mathrm{Ca}^{2+}$ signaling in astrocytes by PUFA. Stimulation of astrocytes by agonists (ATP, thrombin) induces $\left[\mathrm{Ca}^{2+}\right]_{i}$ change from the resting level of $80 \mathrm{nM}$ to $500-1000 \mathrm{nM}$ during spikes or oscillations. These signals trigger $\mathrm{Ca}^{2+}$-dependent processes. PUFA which are released simultaneously, stimulate elevation of $\mathrm{Ca}^{2+}$ to a new steady state of $\left[\mathrm{Ca}^{2+}\right]_{\mathrm{i}}$, which has an intermediate level of $150-200 \mathrm{nM}$. At this elevated level, $\left[\mathrm{Ca}^{2+}\right]_{\mathrm{i}}$ spikes and oscillations are suppressed, whereby the $\mathrm{Ca}^{2+}$-triggered processes are blocked (arrow with the cross). PUFA can also acutely decrease agonist-induced $\mathrm{Ca}^{2+}$-responses (arrow with hammerhead).

oscillations are suppressed. Thus, a large part of $\mathrm{Ca}^{2+}$-triggered processes is blocked (left part in Fig. 5). The $\mathrm{Ca}^{2+}$ system becomes less sensitive to stimulation and extracellular PUFA have a protective role.

Special attention should be given in the future to the investigation of mechanisms leading to a new steady state level of $\left[\mathrm{Ca}^{2+}\right]_{\mathrm{i}}$. Here we show that astrocytes after prolonged stimulation by AA and DHA enter into the state where they become virtually unexcitable by external stimuli which induce an increase in $\left[\mathrm{Ca}^{2+}\right]_{i}$. For such bistability, a positive feedback loop is necessary [81]. PLA 2 could play a key role in the regulation. Excessive, pathological stimulation of the cells leads to a large rise in $\left[\mathrm{Ca}^{2+}\right]_{\mathrm{i}}$ and activation of other pathways, such as MAPK, PKA, which in turn acti- vates $\mathrm{PLA}_{2}$ and stimulates release of AA and DHA from cellular phospholipids. Then, these PUFA bring the $\mathrm{Ca}^{2+}$ level to the new elevated steady state and block cellular communication, which relies on $\left[\mathrm{Ca}^{2+}\right]_{\mathrm{i}}$ spikes or oscillations.

An intriguing question is still why DHA and AA differ from EPA in their action on $\left[\mathrm{Ca}^{2+}\right]_{\mathrm{i}}$. Knowledge about this question is important not only for understanding the mechanisms of $\left[\mathrm{Ca}^{2+}\right]_{\mathrm{i}}$ regulation, but also for understanding the relations between n-3 PUFA (22:6n-3 DHA and 20:5n-3 EPA) and n-6 PUFA (20:4n-6 AA). These three PUFA are all very similar in their chemical structure. The molecular mechanism, which discriminates between these fatty acid chains, is still unknown [87]. In many studies opposite effects between 
these two classes of fatty acids have been observed. However, in $\left[\mathrm{Ca}^{2+}\right]_{i}$ regulation in astrocytes, extracellular DHA and AA have the same effects, either positive or negative, while EPA remains ineffective.

Indeed, EPA which, in contrast to AA and DHA, failed to stimulate the release of endogenous AA from $\left[{ }^{3} \mathrm{H}\right]$-prelabeled astrocytes [32] was also inactive in the $\mathrm{Ca}^{2+}$ processes. Different types of $\mathrm{PLA}_{2}$ are definitely important players in regulation of $\mathrm{Ca}^{2+}$ by PUFA, because endogenous release is the only significant source of free PUFA in vivo. Numerous data are now available, which provide clear evidence for the important role of $\mathrm{PLA}_{2}$ in regulating physiological and pathological functions in the CNS [20]. $\mathrm{PLA}_{2}$ have been implicated in the pathology of a number of neurodegenerative diseases, including Alzheimer disease, cerebral ischemia, and neuronal injury caused by excitotoxic agents (reviewed in [20]). Under normal conditions, PLA $_{2}$ isozymes may be involved in neurotransmitter release, long-term potentiation, growth and differentiation, and membrane repair. Release of AA by cPLA 2 may be responsible for arachidonate-regulated $\mathrm{Ca}^{2+}$ current [67]. Recently, an interesting pathway for the participation of PLA $_{2}$ in the regulation of $\mathrm{Ca}^{2+}$ influx was suggested [88]. It was shown that iPLA $A_{2}$, which in smooth muscle cells predominantly localizes to the plasma membrane, is inhibited in resting cells by calmodulin (CaM) [88]. After depletion of calcium stores, the production of a CIF, which is still unknown by nature, displaces the inhibitory $\mathrm{CaM}$ from iPLA 2 , resulting in activation of iPLA $_{2}$ and generation of lysophospholipids, which can serve as CIF and activate SOC and capacitative calcium influx.

In the current work we focused on some aspects of the influence of PUFA on $\left[\mathrm{Ca}^{2+}\right]_{i}$ in astrocytes. The involvement of $\mathrm{PLA}_{2}$ and PUFA in the extremely complex $\left[\mathrm{Ca}^{2+}\right]_{\mathrm{i}}$ signaling network is becoming increasingly clear. Elucidation of negative and positive feedback loops between PUFA and $\mathrm{Ca}^{2+}$ pathways will help to understand the role of PUFA in calcium regulation in brain tissue.

\section{ACKNOWLEDGEMENTS}

This work was supported to G. R. by Bundesministerium für Bildung und Forschung (RUS 04/004) and to M.S. in part by the Russian Foundation for Basic Research (04-04-49357).

\section{REFERENCES}

[1] Youdim KA, Martin A, Joseph JA. Essential fatty acids and the brain: possible health implications. Int J Dev Neurosci 2000, 18: 383-399.

[2] Garcia MC, Ward G, Ma YC, Salem N, Kim HY. Effect of docosahexaenoic acid on the synthesis of phosphatidylserine in rat brain in microsomes and C6 glioma cells. J Neurochem 1998, 70: 24-30.

[3] Farooqui AA, Horrocks LA, Farooqui T. Glycerophospholipids in brain: their metabolism, incorporation into membranes, functions, and involvement in neurological disorders. Chem Phys Lipids 2000, 106: 1-29.

[4] Yao JK, van Kammen DP. Membrane phospholipids and cytokine interaction in schizophrenia. Int Rev Neurobiol 2004, 59: $297-$ 326.

[5] Jump DB. The biochemistry of $n-3$ polyunsaturated fatty acids. J Biol Chem 2002, 277 : 8755-8758.

[6] Baethmann A, Maier-Hauff K, Schurer L, Lange M, Guggenbichler C, Vogt W, Jacob K, Kempski O. Release of glutamate and of free fatty acids in vasogenic brain edema. J Neurosurg 1989, 70: 578-591.

[7] Siesjo BK, Ingvar M, Westerberg E. The influence of bicuculline-induced seizures on free fatty acid concentrations in cerebral cortex, hippocampus, and cerebellum. J Neurochem 1982, 39: 796-802.

[8] Yoshida S, Inoh S, Asano T, Sano K, Kubota M, Shimazaki H, Ueta N. Effect of transient ischemia on free fatty acids and phospholipids in the gerbil brain. Lipid peroxidation as a possible cause of postischemic injury. J Neurosurg 1980, 53: 323-331.

[9] Wolfe LS. Eicosanoids: prostaglandins, thromboxanes, leukotrienes, and other derivatives of carbon- 20 unsaturated fatty acids. J Neurochem 1982, 38: 1-14. 
[10] Katsuki H, Okuda S. Arachidonic acid as a neurotoxic and neurotrophic substance. Prog Neurobiol 1995, 46: 607-636.

[11] Phillis JW, Diaz FG, O'Regan MH, Pilitsis JG. Effects of immunosuppressants, calcineurin inhibition, and blockade of endoplasmic reticulum calcium channels on free fatty acid efflux from the ischemic/reperfused rat cerebral cortex. Brain Res 2002, 957: 12-24.

[12] Lauritzen I, Blondeau N, Heurteaux C, Widmann C, Romey G, Lazdunski M. Polyunsaturated fatty acids are potent neuroprotectors. EMBO J 2000, 19: 1784-1793.

[13] Kim HY, Akbar M, Kim KY. Inhibition of neuronal apoptosis by polyunsaturated fatty acids. J Mol Neurosci 2001, 16: 223-227; discussion 279-284.

[14] Peet M. Eicosapentaenoic acid in the treatment of schizophrenia and depression: rationale and preliminary double-blind clinical trial results. Prostaglandins Leukot Essent Fatty Acids 2003, 69: 477-485.

[15] Folley BS, Doop ML, Park S. Psychoses and creativity: is the missing link a biological mechanism related to phospholipids turnover? Prostaglandins Leukot Essent Fatty Acids 2003, 69: 467-476.

[16] Kudo I, Murakami M. Phospholipase $A_{2}$ enzymes. Prostaglandins Other Lipid Mediat 2002, 68-69: 3-58.

[17] Hirabayashi T, Murayama T, Shimizu T. Regulatory mechanism and physiological role of cytosolic phospholipase A2. Biol Pharm Bull 2004, 27: 1168-1173.

[18] Ackermann EJ, Kempner ES, Dennis EA. $\mathrm{Ca}^{2+}$-independent cytosolic phospholipase $\mathrm{A}_{2}$ from macrophage-like P388D1 cells. Isolation and characterization. J Biol Chem 1994, 269: 9227-9233.

[19] Mancuso DJ, Jenkins CM, Gross RW. The genomic organization, complete mRNA sequence, cloning, and expression of a novel human intracellular membrane-associated calcium-independent phospholipase A(2). J Biol Chem 2000, 275: 9937-9945.

[20] Sun GY, Xu J, Jensen MD, Simonyi A. Phospholipase $A_{2}$ in the central nervous system: implications for neurodegenerative diseases. $\mathrm{J}$ Lipid Res 2004, 45: 205-213.

[21] Phillis JW, O'Regan MH. A potentially critical role of phospholipases in central nervous system ischemic, traumatic, and neurodegenerative disorders. Brain Res Brain Res Rev 2004, 44: 13-47.

[22] Staub F, Winkler A, Peters J, Goerke U, Kempski O, Baethmann A. Clearance and metabolism of arachidonic acid by C6 glioma cells and astrocytes. Neurochem Res 1995, 20: 1449-1456.

[23] Hartung HP, Toyka KV. Leukotriene production by cultured astroglial cells. Brain Res 1987, 435: 367-370.

[24] Seregi A, Simmet T, Schobert A, Hertting G. Characterization of cysteinyl-leukotriene formation in primary astroglial cell cultures. J Pharm Pharmacol 1990, 42: 191-193.

[25] Tocher DR, Bell JG, Sargent JR. Production of eicosanoids derived from 20:4n-6 and 20:5n-3 in primary cultures of turbot (Scophthalmus maximus) brain astrocytes in response to platelet activating factor, substance $\mathrm{P}$ and interleukin-1 $\beta$. Comp Biochem Physiol B Biochem Mol Biol 1996, 115: 215-222.

[26] Moore SA, Yoder E, Murphy S, Dutton GR, Spector AA. Astrocytes, not neurons, produce docosahexaenoic acid (22:6 omega-3) and arachidonic acid (20:4 omega-6). J Neurochem 1991, 56: 518-524.

[27] Amruthesh SC, Boerschel MF, McKinney JS, Willoughby KA, Ellis EF. Metabolism of arachidonic acid to epoxyeicosatrienoic acids, hydroxyeicosatetraenoic acids, and prostaglandins in cultured rat hippocampal astrocytes. J Neurochem 1993, 61: 150-159.

[28] Bezzi P, Carmignoto G, Pasti L, Vesce S, Rossi D, Rizzini BL, Pozzan T, Volterra A. Prostaglandins stimulate calcium-dependent glutamate release in astrocytes. Nature 1998, 391: 281-285.

[29] Felder CC, Kanterman RY, Ma AL, Axelrod J. A transfected $\mathrm{m} 1$ muscarinic acetylcholine receptor stimulates adenylate cyclase via phosphatidylinositol hydrolysis. J Biol Chem 1989, 264: 20356-20362.

[30] Kanterman RY, Felder CC, Brenneman DE, Ma AL, Fitzgerald S, Axelrod J. Alpha 1adrenergic receptor mediates arachidonic acid release in spinal cord neurons independent of inositol phospholipid turnover. J Neurochem 1990, 54: 1225-1232.

[31] Stella N, Tence M, Glowinski J, Premont J. Glutamate-evoked release of arachidonic acid from mouse brain astrocytes. J Neurosci 1994, 14: 568-575.

[32] Sergeeva M, Strokin M, Wang H, Ubl JJ, Reiser G. Arachidonic acid and docosahexaenoic acid suppress thrombin-evoked $\mathrm{Ca}^{2+}$ response in rat astrocytes by endogenous arachidonic acid liberation. J Neurochem 2002 , 82: 1252-1261.

[33] Bruner G, Murphy S. ATP-evoked arachidonic acid mobilization in astrocytes is via a $\mathrm{P}_{2 \mathrm{Y}^{-}}$purinergic receptor. J Neurochem 1990, 55: 1569-1575. 
[34] Stella N, Estelles A, Siciliano J, Tence M, Desagher S, Piomelli D, Glowinski J, Premont J. Interleukin-1 enhances the ATP-evoked release of arachidonic acid from mouse astrocytes. J Neurosci 1997, 17: 2939-2946.

[35] Chen WC, Chen CC. ATP-induced arachidonic acid release in cultured astrocytes is mediated by $\mathrm{G}_{\mathrm{i}}$ protein coupled $\mathrm{P}_{2 \mathrm{Y} 1}$ and $\mathrm{P}_{2 \mathrm{Y} 2}$ receptors. Glia 1998, 22: 360-370.

[36] Strokin M, Sergeeva M, Reiser G. Docosahexaenoic acid and arachidonic acid release in rat brain astrocytes is mediated by two separate isoforms of phospholipase $\mathrm{A}_{2}$ and is differently regulated by cyclic AMP and $\mathrm{Ca}^{2+}$. $\mathrm{Br}$ J Pharmacol 2003, 139: 1014-1022.

[37] Budd SL, Lipton SA. Calcium tsunamis: do astrocytes transmit cell death messages via gap junctions during ischemia? Nature Neurosci 1998, 1: 431-432.

[38] Carmignoto G. Reciprocal communication systems between astrocytes and neurones. Prog Neurobiol 2000, 62: 561-581.

[39] Rottingen J, Iversen JG. Ruled by waves? Intracellular and intercellular calcium signalling. Acta Physiol Scand 2000, 169: 203-219.

[40] Perea G, Araque A. Synaptic regulation of the astrocyte calcium signal. J Neural Transm 2005, 112: 127-135.

[41] Araque A, Martin ED, Perea G, Arellano JI, Buno W. Synaptically released acetylcholine evokes $\mathrm{Ca}^{2+}$ elevations in astrocytes in hippocampal slices. J Neurosci 2002, 22: 24432450

[42] Kang J, Jiang L, Goldman SA, Nedergaard M. Astrocyte-mediated potentiation of inhibitory synaptic transmission. Nat Neurosci 1998, 1 : 683-692.

[43] Pasti L, Volterra A, Pozzan T, Carmignoto G. Intracellular calcium oscillations in astrocytes: a highly plastic, bidirectional form of communication between neurons and astrocytes in situ. J Neurosci 1997, 17: 7817-7830.

[44] Shelton MK, McCarthy KD. Hippocampal astrocytes exhibit $\mathrm{Ca}^{2+}$-elevating muscarinic cholinergic and histaminergic receptors in situ. J Neurochem 2000, 74: 555-563.

[45] Verkhratsky A, Orkand RK, Kettenmann H. Glial calcium: homeostasis and signaling function. Physiol Rev 1998, 78: 99-141.

[46] Berridge MJ, Bootman MD, Roderick HL. Calcium signalling: dynamics, homeostasis and remodelling. Nat Rev Mol Cell Biol 2003, 4: 517-529.

[47] Berridge MJ. Capacitative calcium entry. Biochem J 1995, 312: 1-11.
[48] Putney JW Jr. Type 3 inositol 1,4,5-trisphosphate receptor and capacitative calcium entry. Cell Calcium 1997, 21: 257-261.

[49] Putney JW. Capacitative calcium entry revisited. Cell Calcium 1990, 11: 611-624.

[50] Barritt GJ. Receptor-activated $\mathrm{Ca}^{2+}$ inflow in animal cells: a variety of pathways tailored to meet different intracellular $\mathrm{Ca}^{2+}$ signalling requirements. Biochem J 1999, 337: 153-169.

[51] Putney JW Jr, Broad LM, Braun FJ, Lievremont JP, Bird GS. Mechanisms of capacitative calcium entry. J Cell Sci 2001, 114:22232229.

[52] Venkatachalam K, van Rossum DB, Patterson RL, Ma HT, Gill DL. The cellular and molecular basis of store-operated calcium entry. Nat Cell Biol 2002, 4: E263-E272.

[53] Bootman MD, Berridge MJ, Roderick HL. Calcium signalling: more messengers, more channels, more complexity. Curr Biol 2002, 12: R563-R565.

[54] Shuttleworth TJ. What drives calcium entry during $\left[\mathrm{Ca}^{2+}\right]_{\mathrm{i}}$ oscillations? Challenging the capacitative model. Cell Calcium 1999, 25 : 237-246.

[55] Girard S, Clapham D. Acceleration of intracellular calcium waves in Xenopus oocytes by calcium influx. Science 1993, 260: 229-232.

[56] Yule DI, Gallacher DV. Oscillations of cytosolic calcium in single pancreatic acinar cells stimulated by acetylcholine. FEBS Lett 1988, 239: 358-362.

[57] Martin SC, Shuttleworth TJ. Ca ${ }^{2+}$ influx drives agonist-activated $\left[\mathrm{Ca}^{2+}\right]_{\mathrm{i}}$ oscillations in an exocrine cell. FEBS Lett 1994, 352: 32-36.

[58] Sergeeva M, Ubl JJ, Reiser G. Disruption of actin cytoskeleton in cultured rat astrocytes suppresses ATP- and bradikinin-induced $\left[\mathrm{Ca}^{2+}\right]_{i}$ oscillations by reducing the coupling efficiency between $\mathrm{Ca}^{2+}$ release, capacitative $\mathrm{Ca}^{2+}$ entry, and store refilling. Neuroscience 2000, 97: 765-769.

[59] Berridge MJ. Cytoplasmic calcium oscillations: a two pool model. Cell Calcium 1991, 12: $63-72$

[60] Thomas AP, Bird GS, Hajnoczky G, RobbGaspers LD, Putney JW. Spatial and temporal aspects of cellular calcium signaling. FASEB J 1996, 10: 1505-1517.

[61] Wang XB, Osugi T, Uchida S. Muscarinic receptors stimulate $\mathrm{Ca}^{2+}$ influx via phospholipase $\mathrm{A}_{2}$ pathway in ileal smooth muscles. Biochem Biophys Res Commun 1993, 193: 483-489.

[62] Shuttleworth TJ. Arachidonic acid activates the noncapacitative entry of $\mathrm{Ca}^{2+}$ during 
$\left[\mathrm{Ca}^{2+}\right]_{\mathrm{i}}$ oscillations. J Biol Chem 1996, 271 : 21720-21725.

[63] Munaron L, Antoniotti S, Distasi C, Lovisolo D. Arachidonic acid mediates calcium influx induced by basic fibroblast growth factor in Balb-c 3T3 fibroblasts. Cell Calcium 1997, 22: $179-188$.

[64] Mizuno N, Naruse S, Kitagawa M, Ishiguro H, Hayakawa T. Effects of phospholipase $A_{2}$ inhibitors on $\mathrm{Ca}^{2+}$ oscillations in pancreatic acinar cells. Pancreas 2000, 20: 77-83.

[65] Berridge MJ. Cell signalling. A tale of two messengers. Nature 1993, 365: 388-389.

[66] Shuttleworth TJ. Intracellular $\mathrm{Ca}^{2+}$ signalling in secretory cells. J Exp Biol 1997, 200: 303314.

[67] Mignen O, Shuttleworth TJ. IRC $_{\mathrm{ARC}}$, a novel arachidonate-regulated, noncapacitative $\mathrm{Ca}^{2+}$ entry channel. J Biol Chem 2000, 275: 9114 9119.

[68] Luo D, Broad LM, Bird GS, Putney JW. Signaling pathways underlying muscarinic receptor-induced $\left[\mathrm{Ca}^{2+}\right]_{\mathrm{i}}$ oscillations in HEK293 cells. J Biol Chem 2001, 276: 5613-5621.

[69] Ferrier GR, Redondo I, Zhu J, Murphy MG. Differential effects of docosahexaenoic acid on contractions and L-type $\mathrm{Ca}^{2+}$ current in adult cardiac myocytes. Cardiovasc Res 2002, 54: 601-610.

[70] Hirafuji M, Ebihara T, Kawahara F, Minami M. Effect of docosahexaenoic acid on smooth muscle cell functions. Life Sci 1998, 62: 1689-1693.

[71] Hasselmann M, Reimund JM. Lipids in the nutritional support of the critically ill patients. Curr Opin Crit Care 2004, 10: 449-455.

[72] Wijendran V, Hayes KC. Dietary n-6 and n-3 fatty acid balance and cardiovascular health. Annu Rev Nutr 2004, 24: 597-615.

[73] Connor WE. Importance of n-3 fatty acids in health and disease. Am J Clin Nutr 2000, 71: 171S-175S.

[74] Sergeeva M, Strokin M, Wang H, Ubl JJ, Reiser G. Arachidonic acid in astrocytes blocks $\mathrm{Ca}^{2+}$ oscillations by inhibiting storeoperated $\mathrm{Ca}^{2+}$ entry, and causes delayed $\mathrm{Ca}^{2+}$ influx. Cell Calcium 2003, 33: 283-292

[75] Grynkiewicz G, Poenie M, Tsien RY. A new generation of $\mathrm{Ca}^{2+}$ indicators with greatly improved fluorescence properties. J Biol Chem 1985, 260: 3440-3450.

[76] Broad LM, Cannon TR, Taylor CW. A noncapacitative pathway activated by arachidonic acid is the major $\mathrm{Ca}^{2+}$ entry mechanism in rat
A7r5 smooth muscle cells stimulated with low concentrations of vasopressin. J Physiol 1999, 517: $121-134$

[77] Fernando KC, Barritt GJ. Characterisation of the inhibition of the hepatocyte receptor-activated $\mathrm{Ca}^{2+}$ inflow system by gadolinium and SK\&F 96365. Biochim Biophys Acta 1994, 1222: 383-389.

[78] Jorgensen NK, Petersen SF, Hoffmann EK. Thrombin-, bradykinin-, and arachidonic acid-induced $\mathrm{Ca}^{2+}$ signaling in Ehrlich ascites tumor cells. Am J Physiol 1999, 276: C26C37.

[79] Hertelendy F, Molnar M, Jamaluddin M. Dual action of arachidonic acid on calcium mobilization in avian granulosa cells. Mol Cell Endocrinol 1992, 83: 173-181.

[80] Soliven B, Takeda M, Shandy T, Nelson DJ. Arachidonic acid and its metabolites increase $\mathrm{Ca}_{\mathrm{i}}$ in cultured rat oligodendrocytes. Am J Physiol 1993, 264: C632-C640.

[81] Eungdamrong NJ, Iyengar R. Computational approaches for modeling regulatory cellular networks. Trends Cell Biol 2004, 14: 661669.

[82] Ferrell JE Jr. Self-perpetuating states in signal transduction: positive feedback, double-negative feedback and bistability. Curr Opin Cell Biol 2002, 14: 140-148.

[83] Reetz G, Wiesinger H, Reiser G. ATPinduced oscillations of cytosolic $\mathrm{Ca}^{2+}$ activity in cultured astrocytes from rat brain are modulated by medium osmolarity indicating a control of $\left[\mathrm{Ca}^{2+}\right]_{\mathrm{i}}$ oscillations by cell volume. Neurochem Res 1997, 22: 621-628.

[84] Verkhratsky A, Kettenmann H. Calcium signalling in glial cells. Trends Neurosci 1996, 19: $346-352$

[85] Mignen O, Thompson JL, Shuttleworth TJ. Reciprocal regulation of capacitative and arachidonate-regulated noncapacitative $\mathrm{Ca}^{2+}$ entry pathways. J Biol Chem 2001, 276: 3567635683.

[86] Moneer Z, Taylor CW. Reciprocal regulation of capacitative and non-capacitative $\mathrm{Ca}^{2+}$ entry in A7r5 vascular smooth muscle cells: only the latter operates during receptor activation. Biochem J 2002, 362: 13-21.

[87] Lands WE. Stories about acyl chains. Biochim Biophys Acta 2000, 1483: 1-14.

[88] Smani T, Zakharov SI, Csutora P, Leno E, Trepakova ES, Bolotina VM. A novel mechanism for the store-operated calcium influx pathway. Nat Cell Biol 2004, 6: 113-120. 